\title{
On an Empirical Definition of Money for Pakistan
}

\author{
NaJAm us SAqIB and Aliya H. Khan*
}

\section{INTRODUCTION}

In the realm of monetary economics, the question of the appropriate definition of money is both crucial and controversial. Various definitions of money offered by monetary economists differ widely. While narrowly defined money consists of currency and demand deposits only, other broader definitions of money include a host of other assets as well. The choice of the most appropriate monetary aggregate is an empirical issue and needs to be settled empirically.

In the literature a number of methods are available for defining money empirically. To mention only two of them, Meltzer (1963) and Laidler (1966) consider that definition of money the most appropriate which gives the most stable demand function for money while Chetty (1969), Moroney and Wilberatte (1976), Boughton (1981) and Husted and Rush (1984) infer their definition of money on the basis of the degree of substitutability between narrowly defined money and other financial assets. Although the two methods are closely linked, the latter has the advantage of providing a direct measure of the degree of substitutability between various financial assets and also allows for defining money as a sort of weighted average of these assets based on this substitutability rather than a simple-sum aggregation. Hence, we have decided to use this approach in the present study to address the question of the most appropriate definition of money for Pakistan. In particular, we have followed Chetty's model because of its simplicity and straight forwardness.

*The authors are respectively, Research Economist at the Pakistan Institute of Development Economics and Assistant Professor at the Quaid-i-Azam University, Islamabad. They are highly grateful to Prof. Syed Nawab Haider Naqvi, Director, Pakistan Institute of Development Economics for his constant encouragement and help during this research. Thanks are also due to Dr Muhammad Hussain Malik for some valuable comments on an earlier draft of this paper. Editorial help of Dr Ashfaque H. Khan in writing the final draft of this paper is also gratefully acknowledged. Needless to say, the authors alone are responsible for any errors of omission and commission. This is an abridged version of the paper read at the Fifth Annual General Meeting of the Pakistan Society of Development Economists. 


\section{METHODOLOGY AND DATA}

Two alternative definitions of money are popular in Pakistan. The narrowly defined money (M1) consists of currency and demand deposits while the broader concept (M2) also includes time deposits. Thus, the issue of the most appropriate definition of money boils down to the specific question whether time deposits are a good substitute for narrowly defined money. To answer this question, we specify a Chetty-type two asset model:

We assume that the consumer maximizes the utility function:

$$
\cup=\left(\alpha M_{1}^{-e}+\beta T^{-e}\right)^{-1 / e}
$$

subject to the budget constraint:

$$
M^{*}=M_{1}+T /(1+r)
$$

where

$M_{1}=$ Holdings of currency and demand deposits in the current period:

$T=$ Cash value of time deposits of the scheduled banks in the next period $\alpha, \beta>0=$ Constants

$e,(-1<e<\infty)=$ Substitution parameter;

$M^{*}=$ Consumer's cash holdings to be allocated between $M_{1}$ and $T$; and

$r=$ Rate of interest on time deposits

The first order conditions for constrained maximization imply that:

$$
\begin{array}{ll}
\frac{\partial U}{\partial M_{1}} & =\lambda \\
\frac{\partial U}{\partial T} & =\lambda(1+r) \\
M^{*} & =M_{1}+T /(1+r)
\end{array}
$$

where $\lambda$ is the Lagrange multiplier. By solving and manipulating these equations we get:

$$
\frac{\alpha}{\beta}\left(\frac{M_{1}}{T}\right)^{-e-1}=1+r
$$

Taking logarithm of both sides, rearranging the terms and adding a stochastic error term, we obtain the following estimating equation:

$$
\log \frac{M_{1}}{T}=-\frac{1}{1+e} \log \frac{\beta}{\alpha}+\frac{1}{1+e} \log \frac{1}{1+r}+u
$$

The coefficient of $\log (1 / 1+r)$ gives a direct measure of the elasticity of substitution which can be estimated econometrically.

All the data used in this study to estimate Equation (7) are taken from Bulletins and Annual Reports of the State Bank of Pakistan (Various Issues). Figure on $M_{1}$ and $T$ are in million rupees while those on $r$ are in percentages.

\section{ESTIMATION RESULTS}

We first estimated Equation (7) using the Ordinary Least Squares procedure (OLS), but the results suffered from positive serial correlation. To correct this problem we re-estimated the equation using the Cochrane-Orcutt iterative technique. The resulting estimated equation is reported below:

$$
\begin{aligned}
\log \left(M_{1 / T}\right)= & 4.330+1.552 \log \frac{1}{1+r} \\
& (3.620)(3.208) \\
R^{2}= & 0.436 \quad F=10.292 \mathrm{DW}=1.995 \quad \mathrm{DF}=11
\end{aligned}
$$

This equation is satisfactroy in terms of all the conventional statistics. The value of the elasticity of substitution obtained from this equation is 1.552 which implies a value of -0.356 for the substitution parameter $e$. These values lie in the permissible range and imply a convex indifference curve between $M_{1}$ and $T$ which touches the axes. The elasticity of substitution is statistically significant at the 1 percent level but, as seen from the reference points of zero and infinity, its magnitude is not very large. This leads us to conclude that substitution between $M_{1}$ and $T$ does take place though it is not perfect.

The various parameters obtained from the estimated equation can be used to aggregate $M_{1}$ and time deposits. Following Chetty (1969) we assume that $\alpha=1$ and derive the adjusted money stock $\left(M_{a}\right)$ for Pakistan by:

$$
M_{a}=\left(M^{-e}+\beta T^{-e}\right)^{-1 /-e}
$$

We substitute the relevant parameters in Equation (8) to get:

$$
M_{a}=\left(M_{1}^{0.356}+0.061 T^{0.356}\right)^{2.813}
$$


The adjusted money stock series are reported in Table 1 . It can be seen that the values of our adjusted money stock lie between $M_{1}$ and $M_{2}$.

Table 1

$M_{1}, M_{2}$ and Adjusted Money Stock (Rs Million)

\begin{tabular}{|c|c|c|}
\hline$M_{1}$ & $M_{2}$ & $M_{\mathrm{a}}$ \\
\hline $\begin{array}{c}\text { Currency + Demand } \\
\text { Deposits }\end{array}$ & $\begin{array}{c}M_{1}+\text { Scheduled } \\
\text { Bank's Time Deposits }\end{array}$ & $\begin{array}{c}\text { Adjusted } \\
\text { Money stock }\end{array}$ \\
\hline
\end{tabular}

\begin{tabular}{rrrr}
$1971-72$ & 16597.0 & 24668.2 & 19042.5 \\
$1972-73$ & 18895.5 & 28251.8 & 21605.9 \\
$1973-74$ & 21621.9 & 31531.8 & 24715.4 \\
$1974-75$ & 24560.1 & 35820.9 & 28308.4 \\
$1975-76$ & 31002.3 & 46222.6 & 35708.8 \\
$1976-77$ & 38360.2 & 57301.3 & 44113.2 \\
$1977-78$ & 45176.7 & 67856.9 & 51913.6 \\
$1978-79$ & 52859.0 & 79164.5 & 60685.4 \\
$1979-80$ & 62300.5 & 92493.5 & 71379.0 \\
$1980-81$ & 69188.0 & 103280.0 & 79532.5 \\
$1981-82$ & 79254.5 & 119826.5 & 91618.9 \\
$1982-83$ & 93452.0 & 145556.0 & 107982.0 \\
$1983-84$ & 103884.5 & 164766.0 & 119925.6 \\
$1984-85$ & 115454.0 & 181889.5 & 133380.6 \\
\hline
\end{tabular}

\section{SUMMARY AND CONCLUSIONS}

An appropriate definition of money is important from the point of view of both economists and policy-makers. In Pakistan two alternative definitions of money are popular. The narrow money stock consists of currency and demand deposits while the broad definition also includes time deposits. The question to be answered is whether time deposits should be included in the definition of money. We have tried to answer this question with the help of a two-asset Chetty-type model. Our main finding is that time deposits are much less than perfect substitute for money so that the true definition of money is the adjusted money stock calculated in this study. The magnitude of this aggregate is greater then $M_{1}$ but smaller than $M_{2}$
The new monetary aggregate presented in this study may be beneficial for researchers and policy-makers working in the area of monetary economics. However, since its value depends on behavioural parameters, the empirical aggregate would need to be re-estimated periodically to take account of the fact that the elasticity of substitution may change over time.

\section{REFERENCES}

Boughton, J. M. (1981). "Money and its Substitutes". Journal of Monetary Economics. Vol. VIII, No. 3.

Chetty, V. K. (1969). "On Measuring Nearness of Near-Moneys". American Economic Review. Vol. LIX, No. 3 .

Husted, S., and M. Rush (1984). "On Measuring the Nearness of Near-Moneys: Revisited". Journal of Monetary Economics. Vol. XIV, No. 2.

Laidler, D. (1966). "Some Evidence on the Demand for Money". Journal of Political Economy. Vol. LXXIV, No. 1.

Meltzer, A. H. (1963). "The Demand for Money: The Evidence from the Time Series”. Journal of Political Economy. Vol. LXXI, No. 3.

Moroney, J. R., and B. J. Wilberatte (1976). "Money and Money Substitutes". Journal of Money Credit and Banking. Vol. VIII, No. 1.

Pakistan, State Bank of (Various Issues). Bulletin. Karachi.

Pakistan, State Bank of (Various Issues). Annual Report. Karachi 
do not explain the logic of constructing the money stock in this way. How total utility and adjusted money stock become one and the same thing, I think, needs to be explained. Similarly, to estimate the utility level the authors need separate values of the coefficients $\alpha$ and $\beta$ of the CES function. But they are able to estimate the ratio of the coefficients $(\alpha / \beta)$. Therefore, they have to assume value of one of the

\section{"On an Empirical Definition of Money for Pakistan"}

Comments on

The paper addresses an important issue of monetary economics. I think that all the economists agree that the appropriate definition of money is an empirical issue. However, in the case of Pakistan not much empirical work has been done to determine the appropriate definition of money. To my knowledge, this is the second paper which deals directly with the issue of definition of money. The first paper appeared in a recent issue (Autumn, 1988) of The Pakistan Development Review.

In the literature on monetary economics, we find more than one definition of money. Each definition of money specifies certain monetary assets which ought to be included in money stock. The approach followed in the present paper suggests that to decide which monetary assets should be included in defining money, we should consider the substitutability of the assets. Only those assets which are empirically found to be substitutes can be used simultaneously to define money. The assets can simply be added together when the degree of substitution is perfect among them. In case of less than perfect substitution, a sort of weighted average of the assets may be used.

My first and major comment deals with the scope and coverage of the paper. The authors have estimated elasticity of substitution between $M_{1}$ (currency + demand deposits) and $T$ (time deposits held at the commercial banks). There are a number of other important monetary assets not covered in the study. For example, saving deposits held in the form of profit-loss-sharing accounts at the commercial banks. These are chequeable deposits with a rate of return and differ from demand deposits in terms of liquidity in the sense that the depositor needs to give an advance notice of one week to the bank to withdraw a large sum from his account. Similarly, national savings schemes available at the Post Offices and National Savings Centres are not included in the analysis. These savings schemes are in fact time deposits offering higher rates of return than those offered by the commercial banks. As a consequence, a very large amount of private savings are being kept in the form of these national savings schemes.

The paper does not provide an explanation for a number of important steps involved in the analysis. The authors estimate the parameters of the CES utility function, and then for values of $M_{1}$ and $T$ for different years estimate total utility levels. These total utility levels are called adjusted money stock series. The authors coefficients and they assume $\alpha=1$ without any explanation.

Pakistan Institute of

Muhammad Hussain Malik

Development Economịcs,

Islamabad. 